Gut, 1969, 10, 990-993

\title{
Jejunal transport of electrolytes and water in intestinal disease
}

\author{
SIDNEY F. PHILLIPS AND WALTER C. SCHMID \\ From the Gastroenterology Unit, Mayo Clinic and Mayo Foundation, and the Mayo Graduate School of \\ Medicine (University of Minnesota), Rochester, USA
}

SUMMARY The role of decreased absorption of electrolytes and water by the jejunum in the pathogenesis of diarrhoea was examined in patients with intestinal scleroderma, ileocolitis, gastric hypersecretion, or extensive ileal resection. Absorption of electrolytes and water from a $20-\mathrm{cm}$ segment of jejunum was compared in 10 patients and six healthy volunteers. Malabsorption of electrolytes and water by the jejunum may contribute to diarrhoea in scleroderma, regional enteritis, and gastric hypersecretion. After ileal resection, jejunal absorption was normal.

The healthy jejunum normally absorbs electrolytes and water while producing and maintaining isotonicity of the intestinal contents (Fordtran and Locklear, 1966; Phillips and Summerskill, 1967). In nontropical sprue, secretion of sodium and water by the jejunum contributes to abdominal distension, electrolyte imbalance, and diarrhoea (Cooke, 1957; Schedl and Clifton, 1963; Fordtran, Rector, Locklear, and Ewton, 1967; Schmid, Phillips, and Summerskill, 1969). However, the role of abnormal absorptive function of the jejunum in other intestinal diseases that produce diarrhoea has received little attention. In regional enteritis, jejunal transport mechanisms have not been studied although the diseased ileum absorbed sodium, potassium, and water abnormally (Atwell and Duthie, 1964). Decreased jejunal absorption of isotonic sodium chloride perfusates has been noted in two patients with ulcerogenic islet-cell tumour and diarrhoea (Hebert, Gustke, and Soergel, 1968). After ileal resection, glucose absorption by the jejunum was augmented (Dowling and Booth, 1966), but there was no report of water and electrolyte transport.

To evaluate the role of jejunal dysfunction in diarrhoeal states, absorption of electrolytes and water was measured by perfusing the jejunum with isotonic electrolyte solutions in patients who had intestinal scleroderma, regional enteritis, gastric hypersecretion, or ileal resection. Results were compared with those from similar studies performed previously on healthy volunteers (Schmid et al, 1969). Abnormal absorption of water and electrolytes by the jejunum may contribute to the diarrhoea that accompanies intestinal scleroderma, regional enteritis, and gastric hypersecretion due to islet-cell tumour of the pancreas. Absorption of water and electrolytes by the jejunum remaining after extensive resection of the ileum was normal.

\section{METHODS}

The technique for intraluminal perfusion of a $20-\mathrm{cm}$ segment of jejunum, utilizing an occluding balloon, has been described elsewhere (Phillips and Summerskill, 1967). A composite polyvinyl tube with four lumens and incorporating an occluding balloon was passed by mouth and positioned fluoroscopically with the balloon at the duodenojejunal junction. The balloon was inflated with $50 \mathrm{ml}$ of water to occlude the intestine, and the bowel proximal to the balloon was aspirated continuously. The isotonic perfusing solutions were at $37^{\circ} \mathrm{C}$ and $p \mathrm{H} 8.0$ and contained sodium $135 \mathrm{mM}$, potassium $15 \mathrm{mM}$, chloride $115 \mathrm{mM}$, and bicarbonate $35 \mathrm{mM}$; a poorly absorbed reference marker (phenolsulphonphthalein) and $0.1 \%$ glucose were added. Solutions were infused by a pump calibrated to deliver $10 \mathrm{ml} / \mathrm{min}$ (Beckman model 746) immediately distal to the balloon and were collected by gentle, continuous suction (Gomco model 761 ) $20 \mathrm{~cm}$ caudad. Steady-state conditions were achieved before three sequential samples were collected for analysis, using routine methods (Phillips and Summerskill, 1967). Absorption or secretion of water and electrolytes was calculated from the mean of the three collection periods, with reference to phenolsulphonphthalein using standard formulae. Results are expressed as microequivalents of electrolyte or millilitres of water absorbed or secreted per $20 \mathrm{~cm}$ of jejunum per minute (Phillips and Summerskill, 1967).

Clinical data on the 10 patients are given in Table I. In two patients, scleroderma (progressive systemic sclerosis) was diagnosed on the basis of sclerodactylia and the radiological and manometric features of oesophageal aperistalsis. Chronic weight loss, diarrhoea with steatorrhoea, and abnormal radiological appearances of the small 
TABLE I

CLINICAL STATUS OF 10 PATIENTS WITH SEVERE INTESTINAL DISEASE

\begin{tabular}{|c|c|c|c|c|c|c|}
\hline $\begin{array}{l}\text { Patient } \\
\text { No. }\end{array}$ & $\begin{array}{l}\text { Sex and } \\
\text { Age }(y r)\end{array}$ & Disease & Diarrhoea & Steatorrhoea & Jejunal Mucosa & Comment \\
\hline 1 & $\mathrm{~F}, \quad 48$ & Scleroderma & Yes & Yes & Focal jejunitis & Improved with antibiotic \\
\hline 2 & M, 62 & Scleroderma & Yes & Yes & Normal & Improved with antibiotics \\
\hline 3 & M, 36 & Regional enteritis & Yes & - & Normal $^{1}$ & Ileocolit is ${ }^{2}$ \\
\hline 4 & $\mathrm{~F}, \quad 19$ & Regional enterit is & Yes & - & Normal $^{1}$ & Ileocolit is ${ }^{2}$ \\
\hline 5 & M, 43 & Regional enterit is & Yes & - & Normal $^{1}$ & Ileocolit is \\
\hline 6 & F, $\quad 69$ & Regional enterit is & Yes & - & Normal $^{1}$ & Ileocolitis \\
\hline 7 & M, 58 & Gastric hypersecretion & Yes & Yes & $\begin{array}{c}\text { Brunner-gland } \\
\text { hyperplasia }\end{array}$ & $\begin{array}{l}\text { Severe gastric hypersecre- } \\
\text { tion, no ulcer found at } \\
\text { laparotomy }\end{array}$ \\
\hline 8 & F, $\quad 45$ & Intestinal resection & Yes & Yes & - & $\begin{array}{l}\text { Less than } 100 \mathrm{~cm} \text { of jejunum } \\
\text { remaining }\end{array}$ \\
\hline 9 & F, $\quad 61$ & Intestinal resection & Yes & Yes & - & $\begin{array}{l}\text { Less than } 100 \mathrm{~cm} \text { of } \\
\text { jejunum remaining }\end{array}$ \\
\hline 10 & $F, \quad 63$ & Intestinal resection & Yes & Yes & - & $\begin{array}{l}120 \mathrm{~cm} \text { of jejunum } \\
\text { remaining }\end{array}$ \\
\hline
\end{tabular}

${ }^{1}$ No involvement of jejunum at subsequent operation.

${ }^{2}$ Previous resection of terminal ileum.

bowel also were present, suggestive of scleroderma of the small intestine. Faecal microorganisms were obtained on culture of fasting jejunal aspirates, and clinical improvement was obtained by the prolonged use of broadspectrum antibiotics. One patient (no. 2) received treatment with tetracyclines before each of two studies done one year apart, and the other patient was studied before treatment.

The four patients with regional enteritis all had active ileocolitis, two having had resection of a short segment of the ileum $(15 \mathrm{~cm}$ and $25 \mathrm{~cm}$, respectively) and the ascending colon. In all four patients, subsequent abdominal exploration was required because the disease extended into the ileum or colon, but no macroscopic evidence of inflammatory disease of the jejunum was found at operation.

The patient with gastric hypersecretion (basal, 19.0 m-equiv/ $\mathrm{HCl} /$ hour; peak rate after maximal stimulation with betazole, 75.0 m-equiv/hour) had watery diarrhoea for 10 years. Peptic ulceration was not present at subsequent surgery when an inoperable pancreatic islet-cell tumour and hypertrophy of the Brunner glands were found. The diarrhoea, controlled before operation by continuons gastric suction, was relieved by vagotomy and partial gastrectomy.

Three patients with extensive intestinal resection had watery diarrhoea and steatorrhoea. In two patients resection of the ileum had been performed for vascular occlusion; the third patient had two previous resections of the ileum for regional enteritis, but there was no clinical or laboratory evidence of recurrent disease.

The control subjects were six healthy volunteers, 22 to 51 years old, details on whom have already been reported (Schmid et al, 1969).

\section{RESULTS}

Because the concentrations of individual electrolytes

TABLE II

ABSORPTION OF WATER AND ELECTROLYTES BY 20 CM OF JEJUNUM ${ }^{1}$

\begin{tabular}{|c|c|c|c|c|c|c|}
\hline \multirow{2}{*}{$\begin{array}{l}\text { Patient } \\
\text { No. }\end{array}$} & \multirow[t]{2}{*}{ Disease } & \multirow[t]{2}{*}{ Water $(\mathrm{ml} / \mathrm{min})$} & \multicolumn{4}{|c|}{ Electrolytes $(\mu$-equiv/min) } \\
\hline & & & Sodium & Potassium & Chloride & Bicarbonate \\
\hline $\begin{array}{l}1 \\
2\end{array}$ & $\begin{array}{l}\text { Scleroderma } \\
\text { Scleroderma }\end{array}$ & $\begin{array}{l}-3 \cdot 1 \\
0.3 \text { and } 0.3\end{array}$ & $\begin{array}{r}-427 \\
58 \text { and } 55\end{array}$ & $\begin{array}{l}-3 \\
20 \text { and } 19\end{array}$ & $\begin{array}{l}-353 \\
-22 \text { and }-45\end{array}$ & $\begin{array}{l}-7 \\
\text { Not calculated } \\
\quad \text { and } 117\end{array}$ \\
\hline 3 & Regional enteritis & -0.2 & -46 & 14 & -64 & 48 \\
\hline 4 & Regional enterit is & 0.8 & 91 & 12 & 10 & 103 \\
\hline 5 & Regional enterit is & $\mathbf{0} \cdot \mathbf{2}$ & 75 & 27 & -119 & 254 \\
\hline 6 & Regional enterit is & 0.4 & 92 & 12 & 26 & 48 \\
\hline 7 & Gastric hypersecretion & $-0 \cdot 1$ & 29 & 19 & -38 & 79 \\
\hline 8 & Intestinal resection & 1.4 & 181 & 14 & 93 & 85 \\
\hline 9 & Intestinal resection & $1 \cdot 5$ & 230 & 43 & 135 & 124 \\
\hline 10 & Intestinal resection & $1 \cdot 4$ & 260 & 26 & 76 & Not calculated \\
\hline \multicolumn{7}{|c|}{ Control $(n=16)$} \\
\hline \multirow{2}{*}{\multicolumn{2}{|c|}{$\begin{array}{l}\text { Mean } \\
\text { Range }\end{array}$}} & $1 \cdot 8$ & 256 & 51 & 101 & 163 \\
\hline & & $1 \cdot 3-2 \cdot 6$ & $198-371$ & $30-60$ & $32-196$ & $121-193$ \\
\hline
\end{tabular}

${ }^{1}$ Negative values :=secretion 
in the test solutions were chosen so that reproducible absorption of all electrolytes could be anticipated (Phillips and Summerskill, 1967), all control subjects absorbed water, sodium, potassium, chloride, and bicarbonate (Table II).

Both patients with scleroderma had abnormal absorption. In fact, secretion was demonstrated in the untreated patient. In the other patient, two studies, performed one year apart and after antibiotic therapy, resulted in decreased absorption and showed close agreement.

Absorption of water and each electrolyte was significantly decreased $(P<0.02)$ in regional enteritis. The patient with islet-cell tumour and gastric hypersecretion also had markedly abnormal absorption.

Despite severe diarrhoea in the three patients with extensive ileal resection, jejunal absorption was normal.

\section{DISCUSSION}

All of the patients had severe, debilitating diseases that affected the gastrointestinal tract and resulted in symptomatic diarrhoea. The defective jejunal absorption of water and electrolytes, although presumably relevant to the frequent watery bowel movements, is only one of several factors that could contribute to diarrhoea. Excretion of faecal fat was excessive in all patients tested, and although the relationship between steatorrhoea and diarrhoea is incompletely understood, steatorrhoea per se may produce diarrhoea under certain circumstances (Skala, Krondl, Vulterinová, Štastná, Vauřínkova, Horáčkovà, and Paříkouá, 1968; Poley and Hofmann, 1968). After ileal resection, which had been performed in five patients, excessive concentrations of bile acids can enter the colon, where they inhibit absorption of water and cause diarrhoea (Poley and Hofmann, 1968; Mekhjian and Phillips, 1968; Mekhjian, Phillips, and Hofmann, 1968). Other factors that could have contributed to diarrhoea include disturbances of motility, decreased absorptive surface, and bacterial colonization of the jejunum. The studies reported here were not designed to define the mechanism of diarrhoea in each disease but rather to examine the contribution made to diarrhoea by malabsorption of water and electrolytes in the jejunum. The amount of glucose in our test solutions $(5.6 \mathrm{mM})$ was greater than the concentration of glucose in about one quarter of jejunal samples obtained after a carbohydrate meal (Olsen and Ingelfinger, 1968). They also found higher concentrations of glucose in some samples (highest $48 \mathrm{mM}$, mean $14.6 \mathrm{mM}$ ) which might be expected to enhance water absorption.
In both of our patients with scleroderma, decreased absorption or secretion of water by the jejunum may have been a factor in diarrhoea, but in addition, each patient had severe steatorrhoea (initial faecal fat excretions of 20 and $40 \mathrm{~g}$ daily), and in one patient, biopsy of jejunal mucosa showed inflammatory infiltration of the lamina propria.

Four patients with regional enteritis had abnormal absorption in a segment of jejunum that was apparently free of the disease. When directly involved with regional enteritis, the ileum absorbs water and electrolytes abnormally (Atwell and Duthie, 1964); however, mucosal function at a distance from the site of enteritis has not been reported previously. In our patients, the jejunum was considered normal at laparotomy; however, mucosal biopsy specimens were not obtained. Minor histological changes of the jejunal mucosa in ulcerative colitis (Salem and Truelove, 1965) and regional enteritis (Shiner and Drury, 1962) have been incriminated as a cause of the steatorrhoea that sometimes complicates these diseases. Similar changes cannot be excluded as a cause of decreased absorption of electrolytes and water in our patients.

Gastric hypersecretion associated with pancreatic islet-cell tumours may be accompanied by steatorrhoea (Summerskill, 1959). The diarrhoea may be related to steatorrhoea but could be augmented by decreased reabsorption of gastric juice in the jejunum, possibly due to jejunitis (Hebert et al, 1968; Shimoda, Saunders, and Rubin, 1968). Hormonal mechanisms also may be relevant; in animals, exogenous gastrin reduces absorption of electrolytes and water (Gardner, Peskin, Cerda, and Brooks, 1967) by the small intestine. Decreased jejunal absorption of water and electrolytes in our patient may have been due to structural changes in jejunal mucosa associated with hyperplasia of Brunner's glands extending into the upper segment of the jejunum, perhaps as a reaction to the abnormally low $p \mathrm{H}$ in this region. However, it is unlikely that abnormal jejunal absorption was the sole cause of diarrhoea, because continuous aspiration of gastric secretion resulted in a prompt decrease in the frequency of bowel movements.

Three patients had normal absorption of water and electrolytes from the jejunum remaining after extensive resection of the ileum. In rats, the ileum undergoes hypertrophy and the absorption of glucose is increased after resection of the jejunum; compensatory changes are less in the jejunum after removal of the ileum (Booth, Evans, Menzies, and Street, 1959; Dowling and Booth, 1967). In man, jejunal absorption of glucose is increased after resection of the ileum (Dowling and Booth, 1966). However, in our patients, no augmentation of 
water and electrolyte absorption was found. Water and electrolyte balance was precarious in each patient because of the severe diarrhoea. Rapid transit through the remaining regions of the intestine, decreased absorptive surface, and inhibition of water absorption in the colon (Mekjhian et al, 1968) may have contributed to diarrhoea.

This investigation was supported in part by research grant AM-6908 from the National Institutes of Health, Public Health Service.

\section{REFERENCES}

Atwell, J. D., and Duthie, H. L. (1964). The absorption of water, sodium, and potassium from the ileum of humans showing the effects of regional enteritis. Gastroenterology, 46, 16-22.

Booth, C. C., Evans, K. T., Menzies, T., and Street, D. F. (1959) Intestinal hypertrophy following partial resection of the small bowel in the rat. Brit. J. Surg., 46, 403-410.

Cooke, W. T. (1957). Water and electrolyte upsets in the steatorrhea syndrome. J. Mt. Sinai Hosp., 24, 221-231.

Dowling, R. H., and Booth, C. C. (1966). Functional compensation after small-bowel resection in man. Lancet, 2, 146-147.

- - - (1967). Structural and functional changes following small intestinal resection in the rat. Clin. Sci., 32, 139-149.

Fordtran, J. S., and Locklear, T. W. (1966). Ionic constituents and osmolarity of gastric and small-intestinal fluids after eating. Amer. J. dig. Dis., 11, 503-521.

- Rector, F. C., Locklear, T. W., and Ewton, M. F. (1967). Water and solute movement in the small intestine of patients with sprue. J. clin. Invest., 46, 287-298.

Gardner, J. D., Peskin, G. W., Cerda, J. J., and Brooks, F. P. (1967). Alterations of in vitro fluid and electrolyte absorption by gastrointestinal hormones. Amer. J. Surg., 113, 57-64.
Hebert, R. J., Gustke, R. F., and Soergel, K. H. (1968). Diarrhea due to gastric hypersecretion. (Abstr.) Clin Res., 16, 447.

Mekhjian, H. S., and Phillips, S. F. (1968). The effect of unconjugated bile acids on absorption and morphology in the canine colon in vivo. (Abstr.) J. Lab. clin. Med., 72, 997.

,-- and Hofmann, A. F. (1968). Conjugated bile salts block water and electrolyte transport by the human colon. (Abstr.) Gastroenterology, 54, 1256.

Olsen, W. A., and Ingelfinger, F. J. (1968). The role of sodium in intestinal glucose absorption in man. J. clin. Invest., 47, 1133-1142.

Phillips, S. F., and Summerskill, W. H. J. (1967). Water and electrolyte transport during maintenance of isotonicity in human jejunum and ileum. J. Lab. clin. Med., 70, 686-698.

Poley, J. R., and Hofmann, A. F. (1968). Diarrhea following ilea resection: pathogenesis and treatment. (Abstr.) J. clin. Invest., 47 (6), 79a-80a.

Salem, S. N., and Truelove, S. C. (1965). Small-intestinal and gastric abnormalities in ulcerative colitis. Brit. med. J., 1, 827-831.

Schedl, H. P., and Clifton, J. A. (1963). Solute and water absorption by the human small intestine. Nature (Lond.), 199, 1264-1267.

Schmid, W. C., Phillips, S. F., and Summerskill, W. H. J. (1969). Jejunal secretion of electrolytes and water in nontropical sprue. J. Lab. clin. Med., 73, 772-783.

Shimoda, S. S., Saunders, D. R., and Rubin, C. E. (1968). The Zollinger-Ellison syndrome with steatorrhoea. II. The mechanisms of fat and vitamin $\mathbf{B}_{12}$ malabsorption. Gastroenterology, 55, 705-723.

Shiner, M., and Drury, R. A. B. (1962). Abnormalities of the small intestinal mucosa in Crohn's disease (regional enteritis). Amer. J. dig. Dis., 7, 744-759.

Skála, I., Krondl, A., Vulterinová, M., Štastná, R., Vauřinkova, H. Horácková, J., and Paříkouá, V. (1968). Composition of feces in steatorrhoea of different etiology: Mutual relationship between the volume of feces, water, dry matter, nitrogen, and fat content. Amer. J. dig. Dis., 13, 204-212.

Summerskill, W. H. J. (1959). Malabsorption and jejunal ulceration due to gastric hypersecretion with pancreatic islet-cell hyperplasia. Lancet, 1, 120-123. 